\title{
Analysis Methods for the Determination of Anthropogenic Additions of P to Agricultural Soils
}

\author{
Richard L. Haney¹, Virginia L. Jin², Mari-Vaughn V. Johnson³, Elizabeth B. Haney4, \\ R. Daren Harmel1', Jeffrey G. Arnold1, Michael J. White ${ }^{1}$ \\ ${ }^{1}$ United States Department of Agriculture-Agriculture Research Service, Grassland, Soil and Water Research \\ Laboratory, Temple, TX, USA \\ ${ }^{2}$ United States Department of Agriculture-Agriculture Research Service, Agroecosystem Management Research \\ Laboratory, University of Nebraska, East Campus, Lincoln, NE, USA \\ ${ }^{3}$ United States Department of Agriculture-Natural Resource Conservation Service, Temple, TX, USA \\ ${ }^{4}$ Texas A\&M University, Texas AgriLife Research \& Extension Center, Temple, TX, USA \\ Email: rick.haney@ars.usda.gov
}

Received 20 January 2015; accepted 9 February 2015; published 10 February 2015

Copyright (C) 2015 by authors and Scientific Research Publishing Inc.

This work is licensed under the Creative Commons Attribution International License (CC BY).

http://creativecommons.org/licenses/by/4.0/

(c) (i) Open Access

\begin{abstract}
Phosphorus loading and measurement is of concern on lands where biosolids have been applied. Traditional soil testing for plant-available $P$ may be inadequate for the accurate assessment of $P$ loadings in a regulatory environment as the reported levels may not correlate well with environmental risk. In order to accurately assess potential $P$ runoff and leaching, as well as plant uptake, we must be able to measure organic $P$ mineralized by the biotic community in the soil. Soils with varying rates of biosolid application were evaluated for mineralized organic $P$ during a 112-day incubation using the difference between $P$ measured using a rapid-flow analyzer (RFA) and an axial flow Varian ICP-OES. An increase in the P mineralized from the treated soils was observed from analysis with the Varian ICP-OES, but not with the RFA. These results confirm that even though organic $P$ concentrations have increased due to increasing biosolid application, traditional soil testing using an RFA for detection, would not accurately portray $P$ concentration and potential $P$ loading from treated soils.
\end{abstract}

\section{Keywords}

Phosphorus, Anthropogenic Additions, Biosolids, Rapid-Flow Analyzer (RFA), Inductively Coupled Plasma (ICP), Texas Commission of Environmental Quality (TCEQ), Soil Organic C (SOC), Total N (TN), Water-Soluble Organic C (WSOC), Water Soluble Organic N (WSON) 


\section{Introduction}

Phosphorus (P) is an essential nutrient for plant growth and is applied to agricultural and urban lands in inorganic (fertilizer) and organic forms (manure, biosolids). While the application of inorganic P is relatively uniform on urban and most agricultural lands, intensive $\mathrm{P}$ application may occur with the application of biosolids from municipal waste processing centers on agricultural fields. The land application of biosolids is a means of waste management that may provide many benefits to soils including soil conditioning [1] [2] and increased aggregate stability [3] [4] soil water content [5] [6], soil organic C (SOC) [7]-[9], soil nitrogen (N) and phosphorus (P) [6] [10] and potential C mineralization and net $\mathrm{N}$ mineralization and immobilization [11]. When biosolids are applied at normal agronomic rates, agricultural productivity may be increased; however, the benefits are limited when crop requirements are exceeded [12]-[14].

Phosphorus concentration in surface water can be tied directly to water quality degradation and can accelerate freshwater eutrophication [15]. Eutrophication is the accumulation of high concentration of inorganic chemicals such as $\mathrm{N}$ or $\mathrm{P}$ in bodies of water, which is often associated with algal blooms. The negative effects of eutrophication range from decreased species diversity to decreased aesthetics [16]. When large populations of algae die, they decompose on the bottom of the lake or reservoir, resulting in a depletion of oxygen in the ecosystem, which can cause fish and aquatic plant to kill. The algal blooms are not only visually unappealing, but also potentially hazardous to human and animal health.

Total P concentrations of $50 \mu \mathrm{g} \cdot \mathrm{L}^{-1}$ are sufficient to sustain chlorophyll concentrations of $10 \mu \mathrm{g} \cdot \mathrm{L}^{-1}$, the lower boundary for a trophic state in temperate streams [17] and eutrophy in lakes [18]. Using the Redfield ratio [19], $\mathrm{P}$ concentrations exceeding $65 \mu \mathrm{g} \cdot \mathrm{L}^{-1}$ are sufficient to support algal growth in many water bodies when nitrate- $\mathrm{N}$ concentrations exceed $10 \mathrm{mg} \cdot \mathrm{L}^{-1}$. It has been shown that these concentrations of total $\mathrm{P}$ can be from ground water in intensive agricultural regions [20]. These non-point sources of P, including both surface runoff and groundwater, can contribute to eutrophication of streams, lakes and rivers. USEPA national lakes assessment survey indicates that based chlorophyll- $a$ concentrations, 20\% of lakes are hypereutrophic [21].

Because of the negative environmental effects of the overloading of $\mathrm{P}$ in surface waters, $\mathrm{P}$ regulations for agricultural lands are being considered, as well as for the land application of biosolids. Regulations for agricultural lands may be centered on a soil-test $\mathrm{P}$ value [15]. Soil-test $\mathrm{P}$ is most commonly related to plant-available $\mathrm{P}$ and may be assessed using many different extractions and analysis methods depending upon which part of the country the soil is analyzed in and the laboratory performing the analysis. As a result, the soil-test P numbers obtained may vary widely.

The most common laboratory analysis for solution $\mathrm{P}$ is by colorimetric analyzers (rapid flow analyzer (RFA), which use chemistries to develop color intensity) or inductively coupled plasma (ICP) which uses heat generated by producing plasma to excite atoms to a higher state of energy and measure the light given off as they fall back to a normal state. Differences between P values obtained from colorimetric and ICP analyses have been noted by some studies, while others indicate there is no significant difference between the analysis methods [22]. The difference between the two instruments is often attributed to the fact that the colorimetric method measures $\mathrm{H}_{2} \mathrm{PO}_{4}$ and $\mathrm{HPO}_{4}$ (inorganic $\mathrm{P}$ ) whereas ICP measures orthophosphate $\mathrm{P}$ plus other forms of organic and inorganic $\mathrm{P}$ [23]. In other words, the organic $\mathrm{P}$ may not be available to form the phosphomolybdate complex needed for color formation and detection in colorimetric analysis [22] [24]. The instrumentation used to analyze P can have a significant influence on P values, even though values obtained using the RFA and ICP are generally correlated [25]. Therefore, depending on instrumentation and soil inputs, phosphate values in soils treated with biosolids, where a significant portion of $\mathrm{P}$ may be attributed to the organic additions, may be underestimated if using colorimetric analyses versus ICP.

In addition, soil-test $\mathrm{P}$ recommendations may not be relevant to the environmental risk associated with soil $\mathrm{P}$ levels [15] because they do not reflect organic P concentrations associated with soil organic matter or P mineralized over time due to natural processes in the soil. Flushes of $\mathrm{P}$ are associated with the natural drying and rewetting of soil with natural rainfall events or irrigation and are partially due to the death of the microbes and decomposition of their cells [26]. Even though P associated with organic matter that is converted to dissolved inorganic $\mathrm{P}$ contributes to $\mathrm{P}$ loading, mineralized $\mathrm{P}$ is not routinely tested for regulatory or fertility assessment.

It is important that the methods of analysis for $\mathrm{P}$ be as sound and comprehensive as possible in order to accurately assess the $\mathrm{P}$ loading associated with runoff from agricultural lands with biosolid application. The objective of this study is to: 1) determine if there is a significant difference between analyses of P from a RFA as com- 
pared to an ICP in soils treated with varying levels of biosolids; 2) determine the fraction of organic P mineralized during 112-day incubation.

\section{Materials and Methods}

The study site where samples were obtained is a municipally operated 485-ha, zero-discharge facility in Travis County, TX. Approximately 220 ha of the facility are used in a year round, continuous field rotation for hay production using coastal Bermuda grass (Cynodon dactylon L.). Currently, one-third of the total biosolids processed by the facility is land-applied as anaerobically digested, Class B biosolids. Following anaerobic digestion, biosolids are belt-pressed to reduce water content then loaded into manure-spreaders for surface application to a perennial no-tillage forage crop system. Annual mean characteristics of dry biosolids based on monthly analysis (November 2006-October 2007) were pH 8.46 (SM 4500-H B); 17.5\% total solids (SM 2540 G); 10,745 mg $\mathrm{NH}_{3}-\mathrm{N} \mathrm{kg}^{-1}$ (SM 4500-NH3 D); 14.7 mg NO $2-\mathrm{N}+\mathrm{NO}_{3}-\mathrm{N} \mathrm{kg}^{-1}$ (EPA 353.2); 52,127 mg TKN kg${ }^{-1}$ (EOA 351.2). Regulated biosolids elemental constituents for dry biosolids at all samplings fall well below the EPA 40 CRF Part 503 limits [27] [28].

A subset of fields within the 220-ha area was sampled for soils used in the present study. Since 1985, a 14-ha field has been treated with $22 \mathrm{dry} \mathrm{Mg}$ biosolids $\mathrm{ha}^{-1} \cdot \mathrm{y}^{-1}$ (25-yr treatment), an agronomic rate below the maximum annual metal loading rate regulated by the Texas Commission of Environmental Quality (TCEQ); 30 TAC $\$ 312.43$ (b) (4); TAC (2005). Annual applications in this field, however, were changed to a single application every 2 years (i.e. bi-annual applications) starting in 2006 to comply with nutrient management plan recommendations to address high soil N levels. In 2001, 105 ha of adjacent row-crop land was acquired and approved by the former Texas Natural Resource Conservation Commission (now TCEQ) as an experimental exemption area to evaluate the potential soil impacts of applying higher rates of biosolids amendments. The exemption area was split into 20 ha, 36 ha, and 49 ha fields for experimental applications of 22, 45, and $67 \mathrm{Mg} \mathrm{ha}^{-1} \cdot \mathrm{y}^{-1}$, respectively, starting in 2002 (8-yr treatment). This newer area was converted to coastal Bermuda grass hay production in 2003. A 2-ha unamended control field is located next to the lowest application rate field. The control field has not received applications of biosolids or commercial fertilizer of any kind since 2000. Soils across the site are Bergstrom silt-loams (fine-silty, mixed, superactive, and thermic Cumulic Haplustolls) and are very deep, welldrained, and moderately permeable, with slopes $<1 \%$.

Surface soils $(0-10 \mathrm{~cm} ; 20 \mathrm{~cm} \times 20 \mathrm{~cm}$ sampling area) were collected in January 2009 from each field (unamended control; 22 dry Mg biosolids ha ${ }^{-1} \cdot \mathrm{y}^{-1}$ for 25 years; 22, 45, and $67 \mathrm{Mg} \mathrm{ha}^{-1} \cdot \mathrm{y}^{-1}$ for 8 years) using a hand spade. No biosolids had been applied to any of the treatment fields for at least 3 months prior to soil sampling. Visible biosolids and plant material were removed from the soil surface prior to sampling. Soils were sampled from three random locations per treatment area and composited by treatment. Soils were sieved through a $2 \mathrm{~mm}$ mesh, large roots removed, and air-dried prior to laboratory incubations.

Initial total soil organic $\mathrm{C}$ (SOC) and total $\mathrm{N}(\mathrm{TN})$ in soils were determined by dry combustion at $680^{\circ} \mathrm{C}$ (Vario Max CHN, Elementar, Hanau, Germany). Soils were extracted with water (10:1 deionized water: dry soil ratio) to simulate available soil nutrients following a natural rain event, as would occur in a field setting. Water-extracts were measured for water-soluble organic C (WSOC) and organic N (WSON) to evaluate the potential in field availability of labile $\mathrm{C}$ and $\mathrm{N}$ for microbial consumption (Apollo 9000, Teledyne Tekmar, Mason, OH). Inorganic $\mathrm{N}$ concentrations in water extracts were measured using continuous flow colorimetry (Flow Solution IV, OI Analytical, College Station, TX). Soil C and N concentrations in the $0-10 \mathrm{~cm}$ soil layer were converted to an area basis using soil bulk densities ( $\mathrm{Mg} \mathrm{ha}^{-1}$ for SOC, TN; kg ha ${ }^{-1}$ for water-soluble $\mathrm{C}$ and $\mathrm{N}$ ). Net $\mathrm{N}$ mineralization ( $\mathrm{mg} \mathrm{N} \mathrm{kg}^{-1} \cdot \mathrm{d}^{-1}$ ) over the incubation period was determined as the difference between water-extractable soil inorganic $\mathrm{N}$ concentrations $\left(\mathrm{NH}_{4}^{+}-\mathrm{N}+\mathrm{NO}_{2}^{-}-\mathrm{N}+\mathrm{NO}_{3}^{-}-\mathrm{N}\right)$ between two consecutive destructive sampling days. Initial P concentrations were colorimetrically determined using a water extract and H3A extract [29]. $\mathrm{CO}_{2}$-C mineralized after 1-day was determined for each of the surface soil samples using the Haney-Brinton Method [30].

Triplicate soil samples from each treatment were moistened to $50 \%$ water-filled pore space and incubated at $25^{\circ} \mathrm{C} \pm 1^{\circ} \mathrm{C}$ in the dark, with destructive sampling at days $0,7,14,28,56$, and 112 . Soil samples ( $40 \mathrm{~g}$ each) were incubated in 1-quart canning jars containing vials with $10 \mathrm{~mL}$ water to maintain humidity. Soils that were destructively harvested were measured for net $\mathrm{P}$ mineralization over time. On the appropriate sampling day, each sample was dried to $40^{\circ} \mathrm{C}$, ground and passed through a $2 \mathrm{~mm}$ sieve. These sub-samples were weighed into 
50-ml plastic centrifuge tubes and received $40 \mathrm{ml}$ of the soil extractant H3A [29], shaken for 10 minutes and centrifuged for $5 \mathrm{~min}$ at $3500 \mathrm{rpm}$. The extracts were filtered through Whatman $2 \mathrm{~V}$ filter paper.

Orthophosphate P concentrations were measured using an OI Analytical segmented rapid flow analyzer (RFA) (Flow Solution IV, OI Analytical, College Station, Texas) and elemental P concentrations were measured with an axial flow Varian ICP-OES from the same extractant. Net P mineralization ( $\mathrm{mg} \mathrm{P} \mathrm{kg}^{-1}$ soil) over the incubation period was determined as the difference between soil extractable $\mathrm{P}$ concentrations $\left(\mathrm{PO}_{4}-\mathrm{P}\right.$ and elemental $\left.\mathrm{P}\right)$ from the initial $\mathrm{P}$ concentrations (day 0 ) and consecutive destructive sampling days (days $7,14,28,56$, and 112). $\mathrm{P}$ mineralization values were compared between the results obtained from the rapid flow analyzer and the axial flow Varian ICP-OES.

Data were tested for normality using the Shapiro-Wilk statistic. One-way ANOVA was used to test the effects of biosolids treatment on net $\mathrm{P}$ mineralization rates over time using pair-wise multiple comparison procedures (Holm-Sidak method). Linear regressions were used to examine correlations between net P mineralization from both instruments. All statistical tests were performed using SigmaPlot ver. 11 (Systat, Inc.).

\section{Results and Discussion}

Surface soils ranged in $\mathrm{pH}$ from 7.2 to 7.7, with the control (unamended soil) having the highest $\mathrm{pH}$ value. The amended soils had significantly higher total soil organic carbon (SOC) than the unamended soil (Table 1). The amended soils had correspondingly increased $\mathrm{C}$ mineralization after 1 day, except the $22 \mathrm{Mg}$ dry biosolids ha ${ }^{-1}$ 8-yr treatment. Total $\mathrm{N}$, total C:N, WSON, soluble organic C:N, $\mathrm{NH}_{4}^{+}-\mathrm{N}, \mathrm{NO}_{3}^{-}-\mathrm{N}$, inorganic $\mathrm{N}$, total soluble $\mathrm{N}$, and total soluble $\mathrm{C}: \mathrm{N}$ were greatest in the soil amended with the two highest application rates. There was a statistically significant difference in H3A extractable $\mathrm{P}$ among each treatment $(\mathrm{P}<0.001)$, with the $22 \mathrm{Mg}$ dry biosolids ha ${ }^{-1} 25$-yr treatment having the greatest H3A extractable P. The $22 \mathrm{Mg}$ dry biosolids ha ${ }^{-1} 25-\mathrm{yr}$ treatment also had significantly more water soluble $P$ than the other treatments $(P<0.001)$. All treatments had significantly greater water soluble $\mathrm{P}$ than the control $(\mathrm{P}<0.001)$.

Table 1. Mean initial soil pH, bulk densities, and total and water-soluble $\mathrm{C}$ and $\mathrm{N}$ in surface soils (0 $10 \mathrm{~cm}$ ) collected from control and biosolids-applied fields.

\begin{tabular}{|c|c|c|c|c|c|c|}
\hline \multirow{3}{*}{ Constituent } & \multirow{3}{*}{ Unit } & \multicolumn{5}{|c|}{ Biosolids application rate (Mg dry biosolids ha-1) } \\
\hline & & 0 & 22 & 22 & 45 & 67 \\
\hline & & Control & 25-year & 8-year & 8-year & 8-year \\
\hline $\mathrm{pH}(1: 10)$ & & 7.7 & 7.4 & 7.4 & 7.4 & 7.2 \\
\hline Bulk density & $\mathrm{g} \cdot \mathrm{cm}^{-3}$ & 1.5 & 1.5 & 1.5 & 1.5 & 1.5 \\
\hline Total SOC & $\mathrm{mg} \cdot \mathrm{kg}^{-1}$ & 31.4 & 45.7 & 41.8 & 48.1 & 59.8 \\
\hline H3A extractable $\mathrm{P}$ & $\mathrm{mg} \cdot \mathrm{kg}^{-1}$ & 5.7 & 73.3 & 30.4 & 39.0 & 46.3 \\
\hline Water soluble P & $\mathrm{mg} \cdot \mathrm{kg}^{-1}$ & 2.0 & 12.1 & 7.7 & 6.7 & 6.2 \\
\hline Total N & $\mathrm{mg} \cdot \mathrm{kg}^{-1}$ & 3.0 & 4.6 & 3.8 & 5.6 & 9.1 \\
\hline Total C:N & & 10.4 & 9.9 & 11.6 & 8.7 & 6.5 \\
\hline Water soluble OC & $\mathrm{kg} \cdot \mathrm{ha}^{-1}$ & 545.0 & 521.0 & 534.0 & 483.0 & 555.0 \\
\hline Water soluble ON & $\mathrm{kg} \cdot \mathrm{ha}^{-1}$ & 37.7 & 45.9 & 55.0 & 143.5 & 165.4 \\
\hline Soluble organic C:N & & 14.5 & 11.6 & 9.8 & 3.4 & 4.8 \\
\hline $\mathrm{NH}_{4}^{+}-\mathrm{N}$ & $\mathrm{kg} \cdot \mathrm{ha}^{-1}$ & 7.5 & 7.9 & 84.0 & 10.0 & 12.6 \\
\hline $\mathrm{NO}_{3}^{-}-\mathrm{N}$ & $\mathrm{kg} \cdot \mathrm{ha}^{-1}$ & 11.1 & 55.9 & 71.4 & 374.7 & 573.6 \\
\hline Inorganic N & $\mathrm{kg} \cdot \mathrm{ha}^{-1}$ & 18.6 & 63.8 & 79.8 & 384.7 & 586.2 \\
\hline Total soluble $\mathrm{N}$ & $\mathrm{kg} \cdot \mathrm{ha}^{-1}$ & 56.3 & 109.7 & 134.8 & 528.2 & 751.7 \\
\hline Total soluble C:N & & 9.7 & 4.7 & 4.1 & 0.9 & 0.7 \\
\hline 1-day $\mathrm{CO}_{2}-\mathrm{C}$ production & $\mathrm{mg} \mathrm{CO}-\mathrm{C} \mathrm{kg}^{-1}$ & 47.7 & 64.5 & 47.1 & 53.4 & 61.5 \\
\hline
\end{tabular}


P mineralization at 7, 28, 56, and 112 days was highly correlated between the ICP and RFA, while the 14-day mineralization numbers were not as strongly correlated, but still related (Figure 1). When P mineralization values obtained from the RFA and ICP were compared for each treatment, we found that values for the control were not correlated (Figure 2). These results were to be expected since very little $\mathrm{P}$ was mineralized from the control when measured both by the ICP and the RFA. P mineralization values for the remaining treatments were highly correlated. Furthermore, H3A and water extractable P, as well as P mineralization values, follow the increased additions of biosolids in the treatments. We speculate that as organic P from the biosolids is mineralized and converted to inorganic $P$, the inorganic $P$ accumulates in the soil.

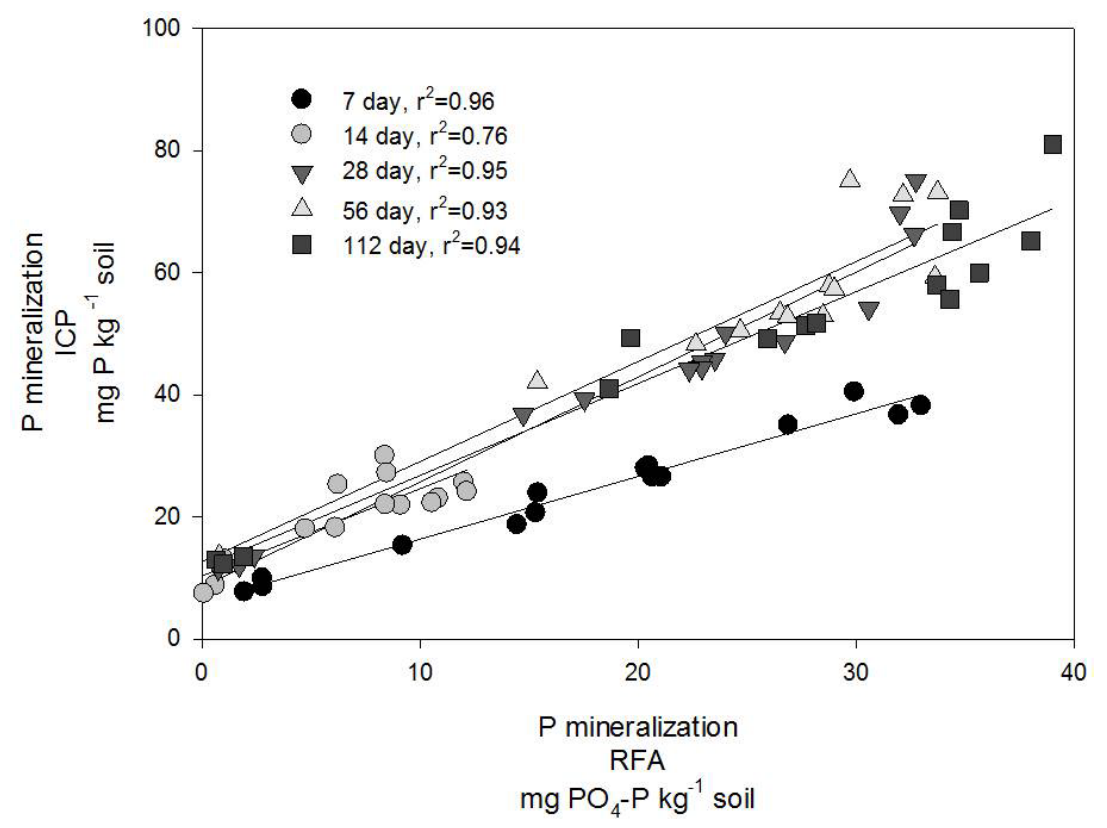

Figure 1. Regression analysis among $\mathrm{P}$ mineralized from rapid flow analyzer vs. inductively coupled plasma analyzer across days of mineralization.

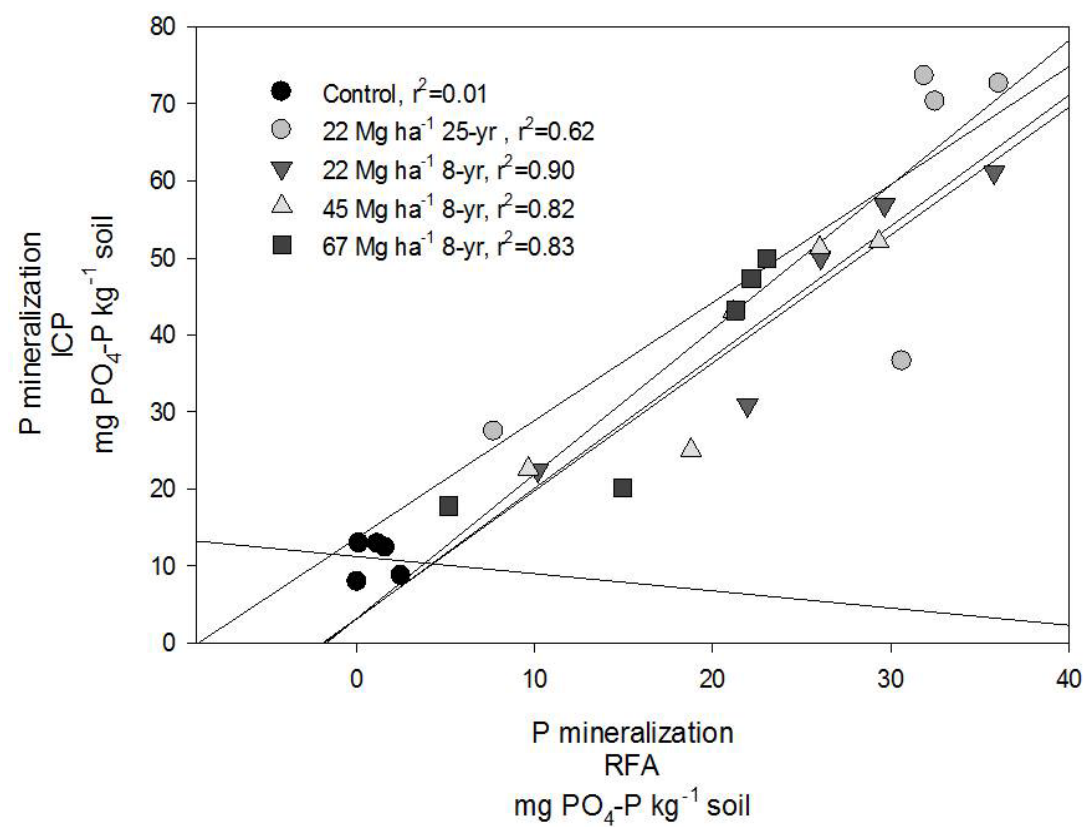

Figure 2. Regression analysis among $\mathrm{P}$ mineralized from rapid flow analyzer vs. inductively coupled plasma analyzer across treatments. 
Even though the relationship among the amounts of P mineralized as measured by the ICP were highly significant $(\mathrm{P}<0.001)$, the values measured by the ICP were greater than those measured by the RFA for all treatments (Figure 3). The difference between the ICP and RFA results are clearly depicted in Figure 4, which illustrates the $\mathrm{P}$ mineralized from both methods at 56 days (the point at which organic P mineralization peaked).

There was not a significant difference in P mineralization among the biosolid treatments when measured using the RFA, excepting the $22 \mathrm{Mg} \mathrm{ha}^{-1} 25$-yr treatment at 28 days incubation (Figure 5). When measured using the ICP, a significant difference was seen in P mineralization between the $22 \mathrm{Mg} \mathrm{ha}^{-1} 25$-yr treatment and the remaining 8 year treatments after 14 days incubation. If the RFA method was used exclusively, the observer

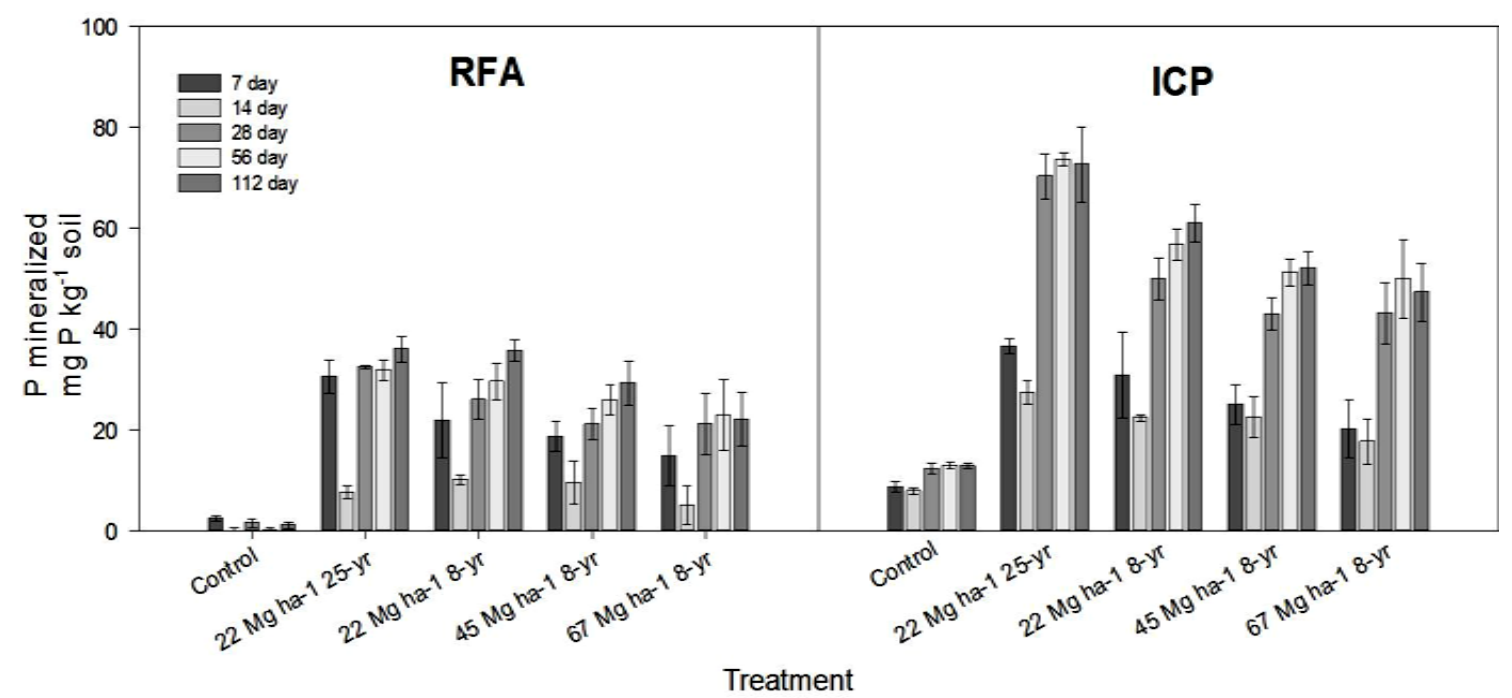

Figure 3. P mineralized from rapid flow analyzer and inductively coupled plasma analyzer across treatments. Error bars represent one standard deviation.

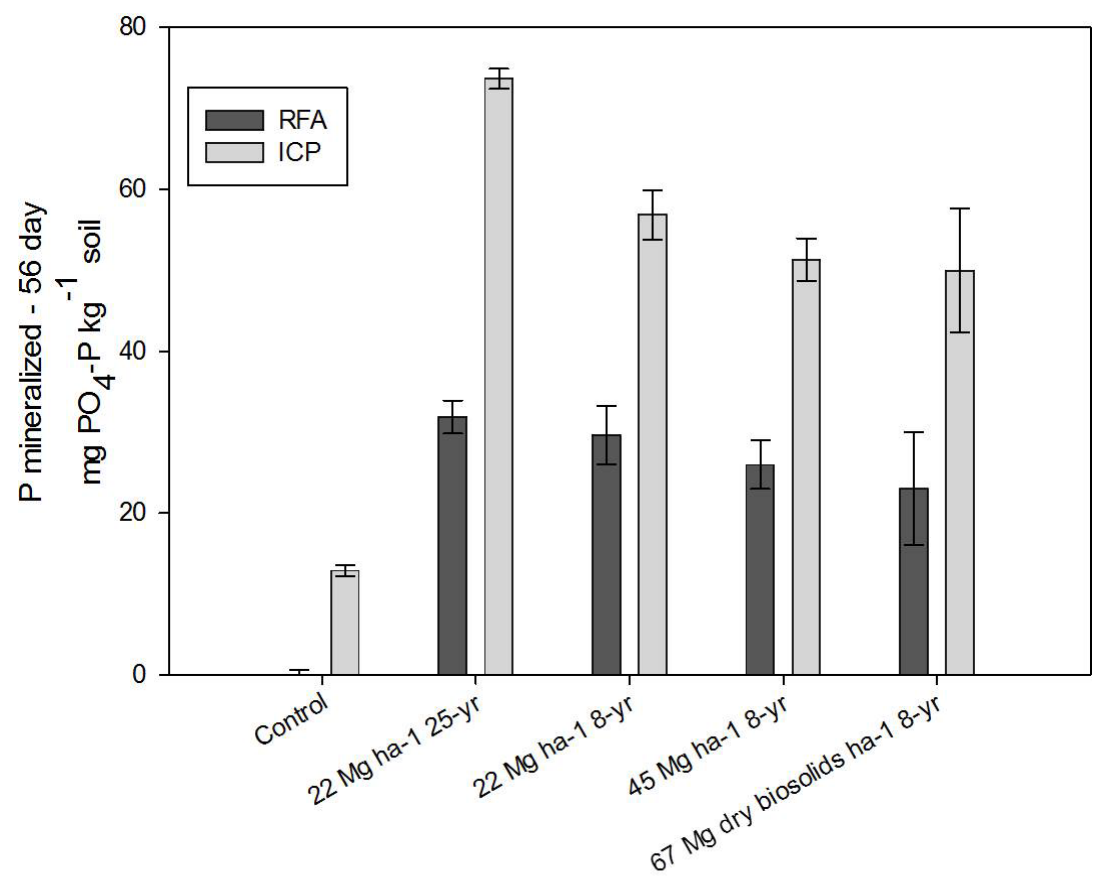

Treatment

Figure 4. P mineralized from rapid flow analyzer and inductively coupled plasma analyzer across treatments after 56 days. At 56 days organic P mineralized had peaked. Error bars represent one standard deviation. 


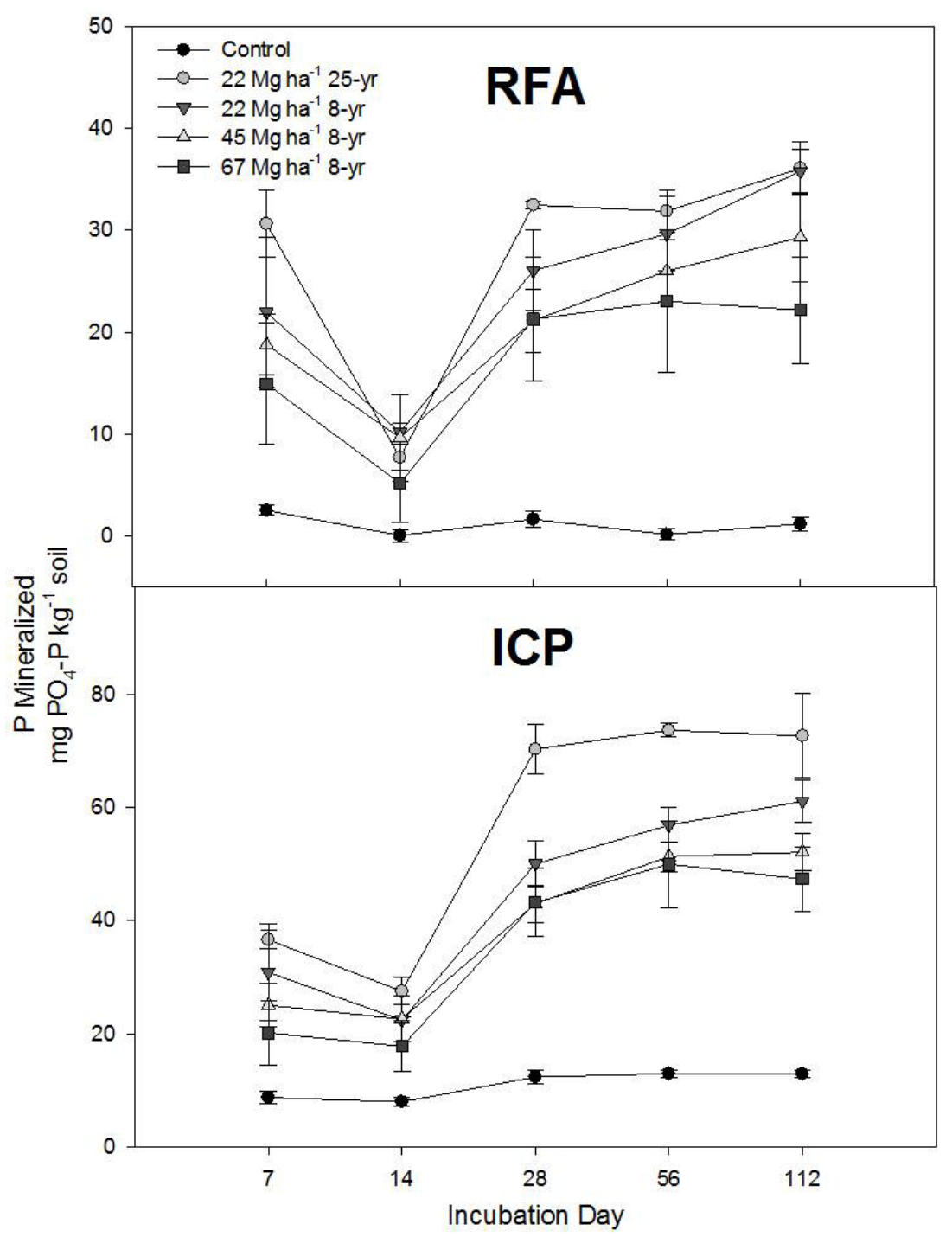

Figure 5. P mineralization over time as determined using the rapid flow analyzer and inductively coupled plasma analyzer methods.

would not see a significant difference among biosolid treatments, which may lead them to believe that there would be no difference in the amount of $\mathrm{P}$ mineralized in each soil.

As shown in Figure 6, differences in the mean organic P mineralization values between the control and all treatments and the $22 \mathrm{Mg}$ dry biosolids ha $^{-1}$ 25-yr treatment and all of the 8-yr treatments are greater than would be expected by chance; meaning there is a statistically significant difference $(\mathrm{P}=<0.001)$. The 22 Mg dry biosolids ha ${ }^{-1} 25$-yr treatment had the greatest amount of organic P mineralization, followed by the three 8-yr treatments, then the control. As expected, as organic matter increases organic P mineralization increases, which was easily discernable using the difference in P measured from the ICP and RFA.

There was no correlation between the $\mathrm{P}$ mineralized obtained using the RFA method and 1-day $\mathrm{CO}_{2}$ production ( $r^{2}=0.19$, Figure 7$)$. The correlation increased, but was still weak, when using the ICP method, with 35\% of the variability in $\mathrm{P}$ mineralized being related to 1-day $\mathrm{CO}_{2}$ production. One-day $\mathrm{CO}_{2}$ results are a direct reflection of the activity of the soil microbial biomass. Fierer and Schimel [31] demonstrated that the flush of $\mathrm{CO}_{2}$ after drying/rewetting soil largely originated from the microbial biomass and Franzluebbers et al. [32] and Haney et al. [33] observed a strong correlation observed between short-term C mineralization and microbial biomass C. Release of potentially mineralizable nutrients and decomposition are generally functions of the soil microbial biomass and its activity. The flush of $\mathrm{CO}_{2}$ after 1 day following rewetting is closely related to potential $\mathrm{C}$ 


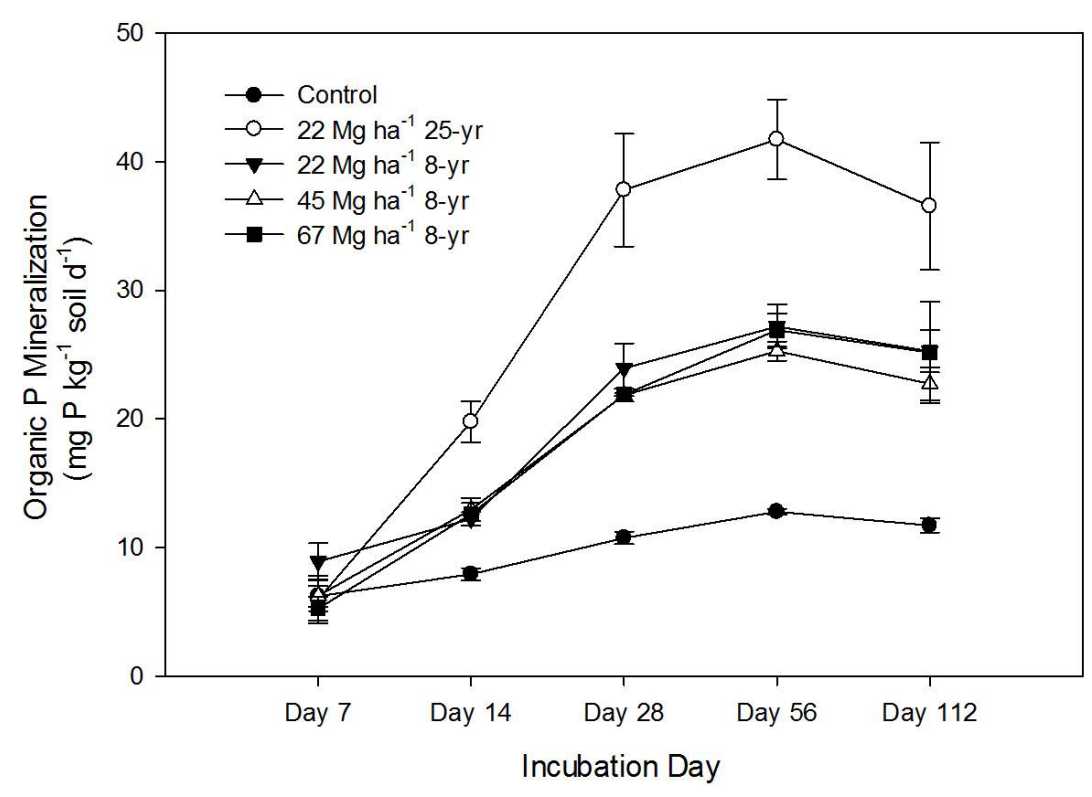

Figure 6. The difference between $\mathrm{P}$ mineralized from inductively coupled plasma analyzer minus rapid flow analyzer from biosolids application over time.

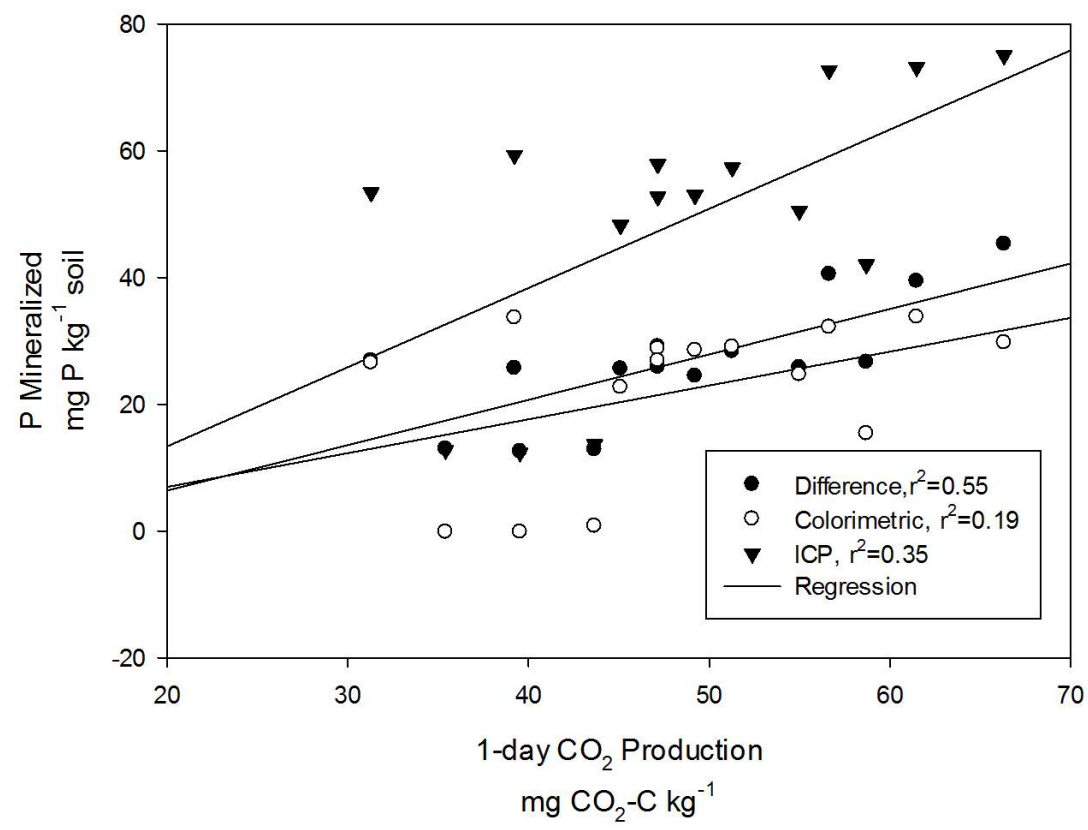

Figure 7. Correlation between P mineralized as measured by the colorimetric method, inductively coupled plasma analyzer, and organic $\mathrm{P}$ mineralized and 1-day $\mathrm{CO}_{2}$ production.

and $\mathrm{N}$ mineralization [32]. It follows that this flush should also be correlated to P mineralization; however, 1-day $\mathrm{CO}_{2}$ is only correlated with difference between the P measured using the ICP and the colorimetric method, or the organic P mineralized. When considering only the difference in P mineralized by the ICP and the RFA, the correlation further increased as 55\% of the variability in P mineralized can be explained by 1-day $\mathrm{CO}_{2}$ values. The additional $\mathrm{P}$ that is detectable by the ICP only may be from the organic P mineralized from the organic fraction (biosolids) of the soil. Little is actually known about the factors that drive microbial P mineralization, but researchers have indicated that microbes mineralize $\mathrm{P}$ as a byproduct of $\mathrm{C}$ acquisition, without incorporating the $\mathrm{P}$ mineralized [34]. 
The results of this study indicate that as organic P concentrations increase due to increasing biosolid application, traditional soil testing using an RFA for detection would not accurately portray $\mathrm{P}$ concentration and potential P loading from treated soils. We recommend using the ICP to measure P mineralized from soils treated with organic P amendments.

\section{References}

[1] Hargreaves, J.C., Adl, M.S. and Warman, P.R. (2008) A Review of the Use of Composted Municipal Solid Waste in Agriculture. Agriculture, Ecosystems \& Environment, 123, 1-14. http://dx.doi.org/10.1016/j.agee.2007.07.004

[2] Singh, R.P. and Agrawal, M. (2008) Potential Benefits and Risks of Land Application of Sewage Sludge. Waste Manage, 28, 347-358. http://dx.doi.org/10.1016/j.wasman.2006.12.010

[3] Ojeda, G., Alcañiz, J.M. and Ortiz, O. (2003) Runoff and Loses by Erosion in Soils Amended with Sewage Sludge. Land Degradation \& Development, 14, 563-573. http://dx.doi.org/10.1002/ldr.580

[4] Tejada, M. and Gonzalez, J.L. (2007) Application of Different Organic Wastes on Soil Properties and Wheat Yield. Agronomy Journal, 99, 1597-1606. http://dx.doi.org/10.2134/agronj2007.0019

[5] Nielsen, G.H., Hogue, E.J., Forge, T. and Nielsen, D. (2003) Surface Application of Mulches and Biosolids Affect Orchard Soil Properties After 7 Years. Canadian Journal of Soil Science, 83, 131-137. http://dx.doi.org/10.4141/S02-034

[6] Kelly, J.J., Favila, E., Hundal, L.S. and Marlin, J.C. (2007) Assessment of Soil Microbial Communities in Surface Applied Mixtures of Illinois River Sediments and Biosolids. Applied Soil Ecology, 36, 176-183. http://dx.doi.org/10.1016/j.apsoil.2007.01.006

[7] Klavidko, E.J. and Nelson, D.W. (1979) Changes in Soil Properties from Application of Anaerobic Sludge. Journal (Water Pollution Control Federation), 51, 325-332.

[8] Crecchio, C., Curci, M., Mininni, R., Ricciuti, P. and Ruggiero, P. (2001) Short-Term Effects of Municipal Solid Waste Compost Amendments on Soil Carbon and Nitrogen Content, Some Enzyme Activities and Genetic Diversity. Biology and Fertility of Soils, 34, 311-318. http://dx.doi.org/10.1007/s003740100413

[9] Parat, C., Chaussod, R., Lévêque, J. and Andreux, F. (2005) Long-Term Effects of Metal Containing Farmyard Manure and sewage Sludge on Soil Organic Matter in a Fluvisol. Soil Biology and Biochemistry, 37, 673-679. http://dx.doi.org/10.1016/j.soilbio.2004.08.025

[10] Bayley, R.M., Ippolito, J.A., Stromberger, M.E., Barbarick, K.A. and Paschke, M.W. (2008) Water Treatment Residuals and Biosolids Coapplications Affect Semiarid Rangeland Phosphorus Cycling. Soil Science Society of America Journal, 72, 711-719. http://dx.doi.org/10.2136/sssaj2007.0109

[11] Jin, V.L., Johnson, M.V.V., Haney, R.L. and Arnold, J.G. (2011) Potential Carbon and Nitrogen Mineralization in Soils from a Perennial Forage Production System Amended with Class B Biosolids. Agriculture, Ecosystems Environment, 141, 3-4. http://dx.doi.org/10.1016/j.agee.2011.03.016

[12] Nielson, G.H., Hogue, E.J., Nielson, D. and Zebarth, B.J. (1998) Evaluation of Organic Wastes as Soil Amendments for Cultivation of Carrot and Chard on Irrigated Sandy Soils. Canadian Journal of Soil Science, 78, 217-225. http://dx.doi.org/10.4141/S97-037

[13] Speir, T.W., Horswell, J., van Schaik, A.P., McLaren, R.G. and Fietje, G. (2004) Composted Biosolids Enhance Fertility of a Sandy Loam Soil under Dairy Pasture. Biology and Fertility of Soils, 40, 349-358. http://dx.doi.org/10.1007/s00374-004-0787-6

[14] Sigua, G.C. and Adjei, M.B. (2005) Cumulative and Residual Effects of Repeated Sewage Sludge Applications: Forage Productivity and Soil Quality Implications in South Florida, USA. Environmental Science and Pollution Research, 12, 80-88. http://dx.doi.org/10.1065/espr2004.10.220

[15] Sharpley, A.N., McDowell, R.W. and Kleinman, P.J.A. (2001) Phosphorus Loss from Land to Water: Integrating Agricultural and Environmental Management. Plant and Soil, 237, 287-307.http://dx.doi.org/10.1023/A:1013335814593

[16] Steffen, W., Crutzen, P.J. and McNeill, J.R. (2007) The Anthropocene: Are Humans Now Overwhelming the Great Forces of Nature. AMBIO: A Journal of the Human Environment, 36, 614-621. http://dx.doi.org/10.1579/0044-7447(2007)36[614:TAAHNO]2.0.CO;2

[17] Dodds, W.K., Jones, J.R. and Welch, E.B. (1998) Suggested Classification of Stream Trophic State: Distributions of Temperate Stream Types by Chlorophyll, Total Nitrogen, and Phosphorus. Water Research, 32, 1455-1462. http://dx.doi.org/10.1016/S0043-1354(97)00370-9

[18] Smith, V.H. (2003) Eutrophication of Freshwater and Coastal Marine Ecosystems a Global Problem. Environmental Science and Pollution Research, 10, 126-139. http://dx.doi.org/10.1065/espr2002.12.142

[19] Redfield, A.C. (1958) The Biological Control of Chemical Factors in the Environment. American Scientist, 46, $205-221$. 
[20] Burkart, M.R., Simpkins, W.W., Morrow, A.J. and Gannon, J.M. (2004) Occurrence of Total Dissolved Phosphorus in Unconsolidated Aquifers and Aquitards in Iowa. Journal of the American Water Resources Association, 40, 827-834.

[21] USEPA (2009) National Lakes Assessment: A Collaborative Survey of the Nation's Lakes. US Environmental Protection Agency, Office of Water and Office of Research and Development, Washington DC, EPA 841-R-09-001.

[22] Pittman, J.J., Zhang, H. and Schroder, J.L. (2005) Differences of Phosphorus in Mehlich-3 Extracts Determined by Colorimetric and Spectroscopic Methods. Communications in Soil Science and Plant Analysis, 36, 1641-1659. http://dx.doi.org/10.1081/CSS-200059112

[23] Kuo, S. (1996) Phosphorus. In: Sparks, D.L., Ed., Methods of Soil Analysis: Part 3, SSSA Book Series No. 5, SSSA and ASA, Madison, 869-919.

[24] Sobeck, S.A. and Ebeling, D.D. (2007) Mass Spectrometric Analysis for Phosphate in Soil Extracts; Comparison of Mass Spectrometry, Colorimetry, and Inductively Coupled Plasma. The Journal of Analytical Sciences Digital Library.

[25] Wolf, A.M., Kleinman, P.J.A., Sharpley, A.N. and Beegle, D.B. (2005) Development of a Water-Extractable Phosphorus Test for Manure: An Interlaboratory Study. Soil Science Society of America Journal, 69, 695-700. http://dx.doi.org/10.2136/sssaj2004.0096

[26] Oehl, F., Frossard, E., Fliessbach, A., Dubois, D. and Oberson, A. (2004) Basal Organic Phosphorus Mineralization in Soils under Different Farming Systems. Soil Biology and Biochemistry, 36, 667-675. http://dx.doi.org/10.1016/j.soilbio.2003.12.010

[27] USEPA (1992) Technical Support Document for Land Application of Sewage Sludge, Volume I. Office of Water, United States Environmental Protection Agency, Washington DC, EPA 822/R-93-001a.

[28] USEPA (1993) Standards for the Use or Disposal of Sewage Sludge; Final Rules. United States Environmental Protection Agency, Washington DC, 40 CFR Part 257 and 503.

[29] Haney, R.L., Haney, E.B., Hossner, L.R. and Arnold, J.G. (2006) A New Soil Extractant for Simultaneous Phosphorus, Ammonium, and Nitrate Analysis. Communications in Soil Science and Plant Analysis, 37, 1511-1523. http://dx.doi.org/10.1080/00103620600709977

[30] Haney, R.L., Brinton, W.F. and Evans, E. (2008) Soil $\mathrm{CO}_{2}$ Respiration: Comparison of Chemical Titration, $\mathrm{CO}_{2}$ IRGA Analysis and the Solvita Gel System. Renewable Agriculture and Food Systems, 23, 171-176. http://dx.doi.org/10.1017/S174217050800224X

[31] Fierer, N. and Schimel, J.P. (2003) A Proposed Mechanism for the Pulse in Carbon Dioxide Production Commonly Observed Following the Rapid Rewetting of a Dry Soil. Soil Science Society of America Journal, 67, 798-805. http://dx.doi.org/10.2136/sssaj2003.0798

[32] Franzluebbers, A.J., Haney, R.L., Honeycutt, C.W., Schomberg, H.H. and Hons, F.M. (2000) Flush of $\mathrm{CO}_{2}$ Following Rewetting of Dried Soil Relates to Active Organic Pools. Soil Science Society of America Journal, 64, 613-623. http://dx.doi.org/10.2136/sssaj2000.642613x

[33] Haney, R.L., Franzluebbers, A.J. and Hons, F.M. (2001) A Rapid Procedure for Prediction of N Mineralization. Biology and Fertility of Soils, 33, 100-104. http://dx.doi.org/10.1007/s003740000294

[34] Spohn, M. and Kuzyakov, Y. (2013) Phosphorus Mineralization Can Be Driven by Microbial Need for Carbon. Soil Biology Biochemistry, 61, 69-75. http://dx.doi.org/10.1016/j.soilbio.2013.02.013 
Scientific Research Publishing (SCIRP) is one of the largest Open Access journal publishers. It is currently publishing more than 200 open access, online, peer-reviewed journals covering a wide range of academic disciplines. SCIRP serves the worldwide academic communities and contributes to the progress and application of science with its publication.

Other selected journals from SCIRP are listed as below. Submit your manuscript to us via either submit@scirp.org or Online Submission Portal.
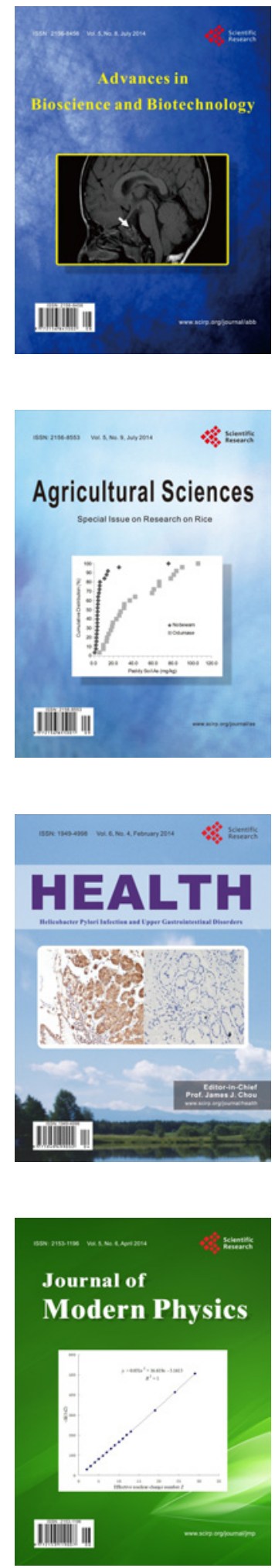
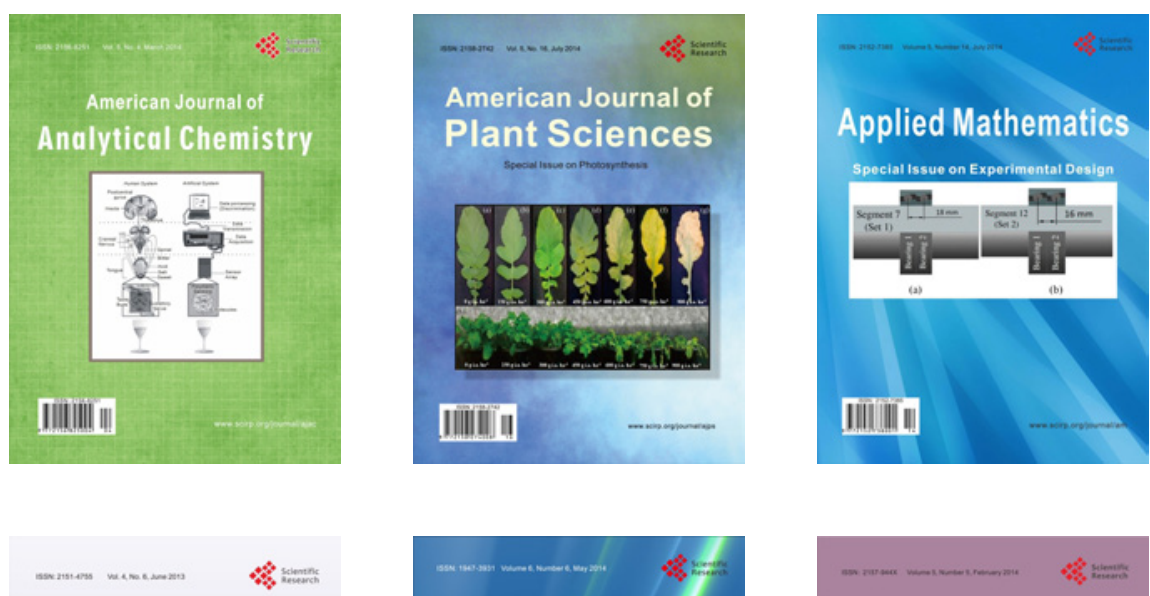

Creative Education
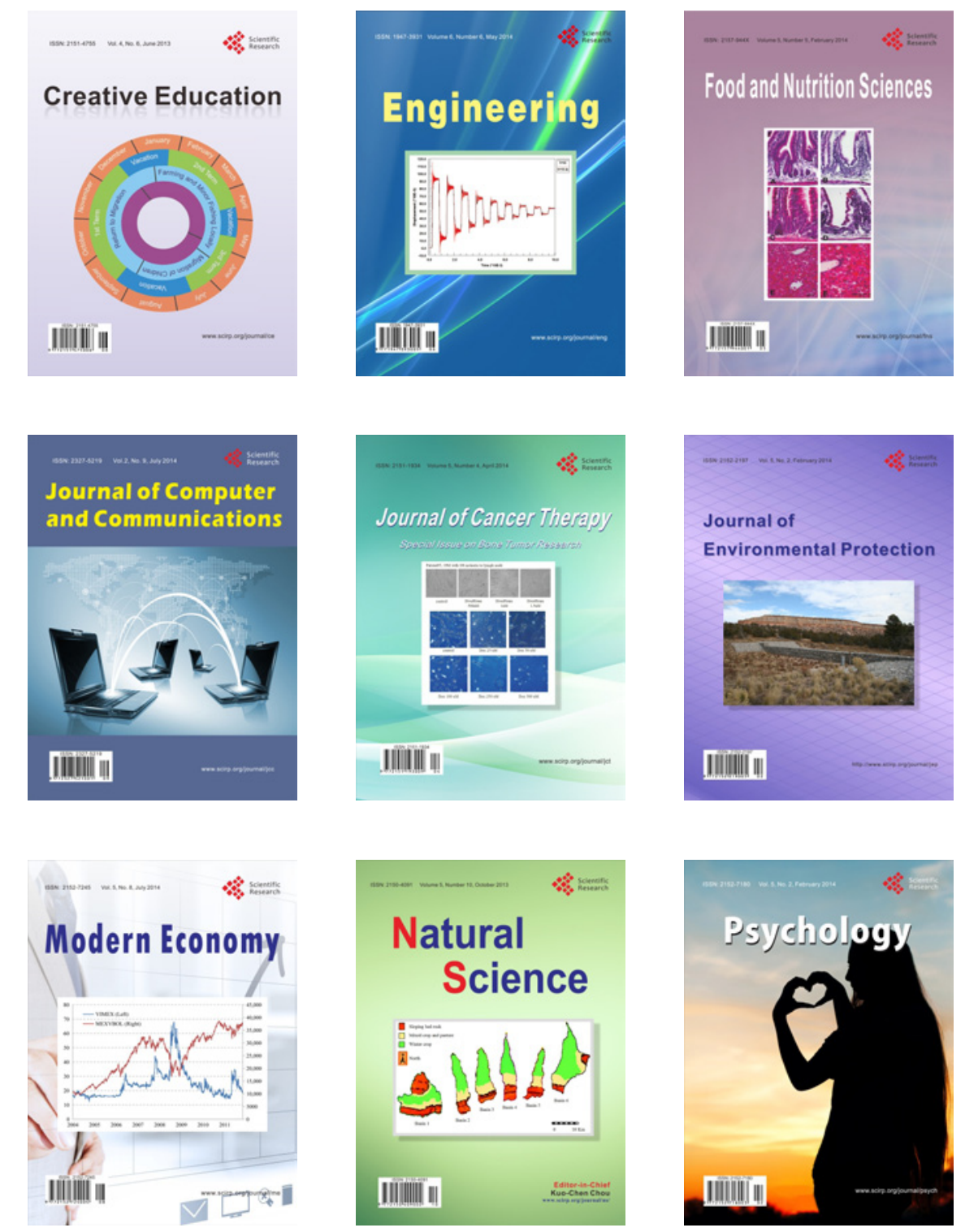